\title{
A practice course to cultivate students' comprehensive ability of photoelectricity
}

Yong Lv, Yang Liu, Chunhui Niu, Lishuang Liu

Yong Lv, Yang Liu, Chunhui Niu, Lishuang Liu, "A practice course to cultivate students' comprehensive ability of photoelectricity," Proc. SPIE 10452, 14th Conference on Education and Training in Optics and Photonics: ETOP 2017, 104525D (16 August 2017); doi: 10.1117/12.2269735

SPIE Event: 14th Conference on Education and Training in Optics and Photonics, ETOP 2017, 2017, Hangzhou, China 


\title{
A practice course to cultivate students' comprehensive ability of
}

\author{
photoelectricity \\ Lv Yong, Liu Yang, Niu Chunhui, Liu Lishuang \\ School of Instrumentation Science and Optoelectronics Engineering, Beijing \\ Information Science \& Technology University, Beijing 100192, China
}

\begin{abstract}
After the studying of many theoretical courses, it's important and urgent for the students from specialty of optoelectronic information science and engineering to cultivate their comprehensive ability of photoelectricity. We set up a comprehensive practice course named "Integrated Design of Optoelectronic Information System" (IDOIS) for the purpose that students can integrate their knowledge of optics, electronics and computer programming to design, install and debug an optoelectronic system with independent functions. Eight years of practice shows that this practice course can train students' ability of analysis, design/development and debugging of photoelectric system, improve their ability in document retrieval, design proposal and summary report writing, teamwork, innovation consciousness and skill.
\end{abstract}

Key words: practice course, comprehensive ability of photoelectricity, optoelectronic information system

\section{Introduction}

Optoelectronic information industry is the most attractive sunrise and the high-tech leading industry in the 21 st century ${ }^{[1,2]}$. To meet the needs of social development, Beijing Information Science and Technology University established the undergraduate program of "optical information science and technology" in 2004, which directly serves the optoelectronic information industry. This program is based on optics and electronics, and combines with computer science, precision machinery and other disciplines, focusing on the design and implementation of optoelectronic systems. In 2005 it was identified as the Beijing brand building program, in 2007 become the school key construction professional and in 2013 its name was changed to be "Optoelectronic information science and engineering".

Many practice and innovation courses are set up, as shown in Fig 1, in addition to course experiments, a three level independent practice system from the fundamental part to the unit design and then the system design is constructed, with all kinds of innovative practice, strengthen the cultivation of students' practical ability and innovation consciousness.

14th Conference on Education and Training in Optics and Photonics: ETOP 2017, edited by Xu Liu,

Xi-Cheng Zhang, Proc. of SPIE Vol. 10452, 104525D - (c) 2017 ICO, IEEE, OSA, SPIE

CCC code: $0277-786 X / 17 / \$ 18 \cdot$ doi: $10.1117 / 12.2269735$ 


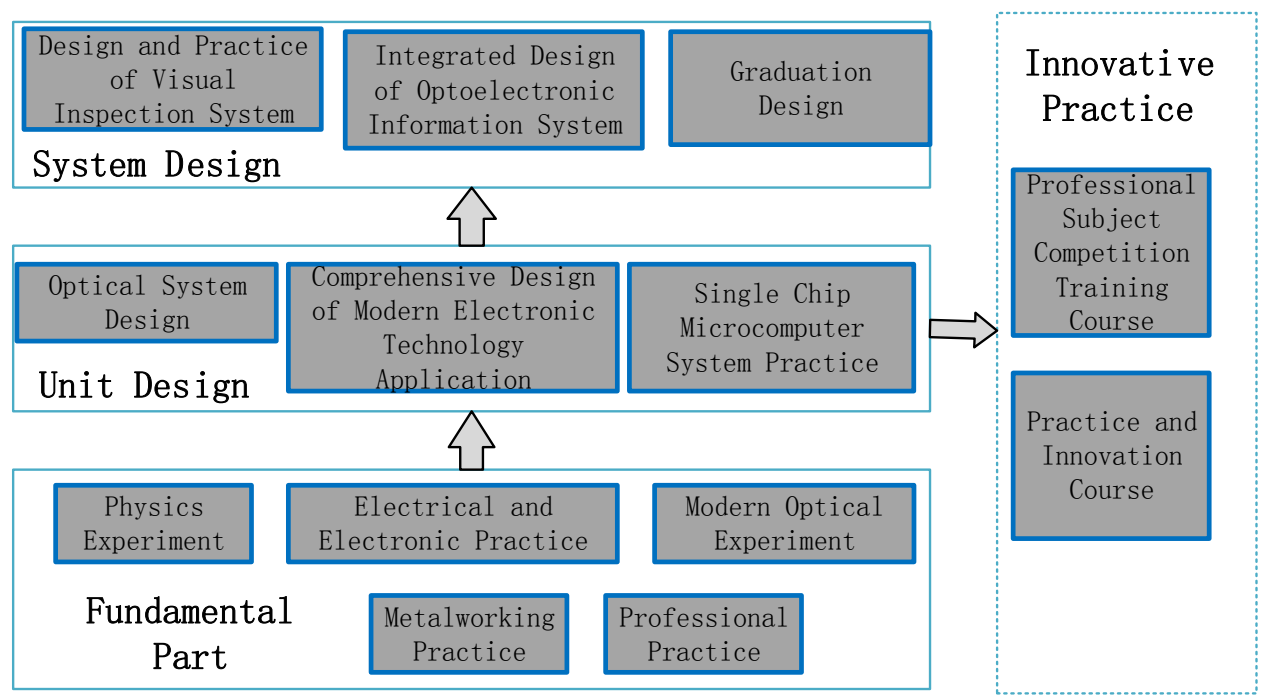

Fig 1. Independent practice system of "Optoelectronic information science and engineering" Program

As an important comprehensive practice activities courses [3,4], Integrated Design of Optoelectronic Information System (IDOIS) is an important part of the three-tier practice system, and the professional compulsory practical courses of the Optoelectronic information science and engineering. On the basis of some prerequisite courses, such as photoelectric detection technology and system, laser principle and application, digital image processing and application and optical system design, combined with the characteristics of optoelectronic engineering, from IDOIS the students can learn and realize an integrated application system of photoelectricity to Solve complex engineering problems.

This course is not only the support for the following graduation design, but also the support for the work after graduation.

On the basis of the completion of theoretical course study and other practical courses, through the study of this course, students can apply the knowledge of optical, mechanical and computer programming, and carry out the process of designing, installing and debugging the optoelectronic information system with independent function. Focus is put on improving students' ability of combining theory with practice and innovation, cultivating comprehensive knowledge and realization methods of product design, process and test technology and other aspects. Through this course, the students will exercise their ability of analysis, design / development and debugging the integrated optoelectronics and electromechanical system, improve their comprehensive quality and ability of scientific information retrieval, conceptual design, summary report writing, teamwork, Innovation consciousness and innovation ability, and personal presentation. So that lay a solid foundation for future related work. 


\section{Integrated Design of Optoelectronic Information System}

\section{(IDOIS)}

\subsection{Course teaching goals}

1. Be able to investigate and survey extensively based on the course task, and to analyze the technical information for effective conclusions;

2. Be able to set the design goals and the system models according to the task requirements, to draw the diagrams for the system components and explain their working principles; to determine the technical indicators for different parts and their input \& output relation; to determine the implementation methods and draw the circuit diagrams or light path diagrams for each part ; to make good selection of the optical or electrical components and calculate their characteristic parameters.

3. Be able to design the experimental program and complete the experimental debugging for each individual part and the whole system; to finish the system test with suitable equipment in order to meet the design requirements; to provide further improvement suggestions on the basis of the experimental data recorded and their analysis.

4. Be able to do the modeling and simulation with computer

5. Be able to make an initial budget for the overall program and improve the cost performance

6. Carry out the research works in a team.

7. Accept the education concerning professional ethics and norms.

8. Be able to pass the opening, mid-term and final stage inspections in terms of reports and oral defense; to write curriculum design instructions, make representations and answer questions correctly.

\subsection{Course contents}

Contents of the course are shown in Tab 1.

Tab 1 course contents

\begin{tabular}{|c|l|l|c|}
\hline $\begin{array}{c}\text { Num } \\
\text { ber }\end{array}$ & \multicolumn{1}{|c|}{ Contents } & \multicolumn{1}{|c|}{ Requirements } & Hours \\
\hline 1 & $\begin{array}{l}\text { Design of Photoelectric } \\
\text { Measurement System for } \\
\text { Object Vibration } \\
\text { Information }\end{array}$ & $\begin{array}{l}\text { To establish a set of system consists of optical, mechanical, } \\
\text { electrical and computer data analysis parts to test the object } \\
\text { vibration and its basic information, such as vibration } \\
\text { frequency, vibration amplitude. }\end{array}$ & $\begin{array}{c}3 \\
\text { weeks }\end{array}$ \\
\hline 2 & $\begin{array}{l}\text { Design of Photoelectric } \\
\text { Communication System }\end{array}$ & $\begin{array}{l}\text { Based on the electro-optical or acousto-optic effect of } \\
\text { crystal, to achieve a typical analog or digital information } \\
\text { (such as voice, letters) communication using light as carrier. }\end{array}$ & $\begin{array}{c}3 \\
\text { weeks }\end{array}$ \\
\hline
\end{tabular}




\begin{tabular}{|c|c|c|c|}
\hline 3 & $\begin{array}{l}\text { Design of Optical Image } \\
\text { Recognition System }\end{array}$ & $\begin{array}{l}\text { To establish an optical image recognition system is and } \\
\text { achieve the optical image recognition using matched filtering } \\
\text { method. }\end{array}$ & $\begin{array}{c}3 \\
\text { weeks }\end{array}$ \\
\hline 4 & $\begin{array}{l}\text { Design of a Photoelectric } \\
\text { Blind Guide }\end{array}$ & $\begin{array}{l}\text { Based on the photoelectric sensing technology, to design a } \\
\text { blind guide, which can guide the blind to walk with functions } \\
\text { of guidance and obstacle avoidance. }\end{array}$ & $\begin{array}{c}3 \\
\text { weeks }\end{array}$ \\
\hline 5 & $\begin{array}{l}\text { Design of Color Confocal } \\
\text { Measurement System }\end{array}$ & $\begin{array}{l}\text { Design and realize a position measurement system on basis } \\
\text { of the color confocal principle. }\end{array}$ & $\begin{array}{c}3 \\
\text { weeks }\end{array}$ \\
\hline 6 & $\begin{array}{l}\text { Research on Principle of } \\
\text { Spatial Filtering and } \\
\text { System Design and } \\
\text { Development }\end{array}$ & $\begin{array}{l}\text { To achieve spatial filtering with computer simulation on the } \\
\text { basis of understanding related concepts, to design and } \\
\text { develop a spatial filtering experimental system to achieve the } \\
\text { filtering. }\end{array}$ & $\begin{array}{c}3 \\
\text { weeks }\end{array}$ \\
\hline 7 & $\begin{array}{l}\text { Design of Mid-distance } \\
\text { Laser Ranging System }\end{array}$ & $\begin{array}{l}\text { To realize the precise distance measurement of the target } \\
\text { based on the method of measuring the laser transmission } \\
\text { time in space. }\end{array}$ & $\begin{array}{c}3 \\
\text { weeks }\end{array}$ \\
\hline 8 & $\begin{array}{l}\text { Design of Automatic } \\
\text { Tracking System for } \\
\text { Shining Things }\end{array}$ & $\begin{array}{l}\text { Design a set of system to automatically track luminous } \\
\text { objects. It can realize automatic tracking for all the luminous } \\
\text { objects (such as solar, LED and laser flare) in the field of } \\
\text { view, which means it is always pointed to the luminous } \\
\text { target. In addition, the system should be anti-jamming to } \\
\text { some extend and can work well indoor. }\end{array}$ & $\begin{array}{c}3 \\
\text { weeks }\end{array}$ \\
\hline 9 & $\begin{array}{lr}\text { Design of } & \text { Micro - } \\
\text { displacement } & \\
\text { Measurement } & \text { System } \\
\text { Based on } & \text { Laser } \\
\text { Interferometry } & \\
\end{array}$ & $\begin{array}{l}\text { To achieve high-precision measurement for } \\
\text { micro-displacement with photodetectors based on the laser } \\
\text { interference method. }\end{array}$ & $\begin{array}{c}3 \\
\text { weeks }\end{array}$ \\
\hline 10 & $\begin{array}{l}\text { Design of Intelligent } \\
\text { Control System for } \\
\text { Photoelectric Tracing } \\
\text { Vehicle }\end{array}$ & $\begin{array}{l}\text { The intelligent vehicle should be able to move forward and } \\
\text { backward, turn left and right, accelerate and slow down with } \\
\text { a given } 8 \text {-word path and meanwhile achieve measuring and } \\
\text { displaying their speed or distance. }\end{array}$ & $\begin{array}{c}3 \\
\text { weeks }\end{array}$ \\
\hline 13 & Others & $\begin{array}{l}\text { Optoelectronic Competition Subjects, Undergraduate } \\
\text { innovation projects }\end{array}$ & $\begin{array}{c}3 \\
\text { weeks }\end{array}$ \\
\hline
\end{tabular}

\subsection{Means for achieving the course aims}

1. Grouping and topic determination: The students are divided into several 3-4 member groups. Each group determines the topic and content of the course by considering the advices from instructors according to preferences. 
2. Schematic formulation: Under the guidance provided by instructors, the students are supposed to analyze the principle, build model, picture out block diagrams, derive the specifications of various modules, figure out the Input/Output relationships, and work out the realizing routines. In this section, the students are specifically supposed to be capable of drawing correctly circuit diagrams and light path diagrams, calculating characteristic parameters, and providing budgets.

3. Opening presentation: The schematic design and budget will be evaluated and graded.

4. Operations in Labs: Students will then implement their task in the labs under guidance. The behavior of each students in the labs including attendance, recordings, and costs will be graded.

5. Teamwork: Within the groups, toward a common goal and with clear job divisions, each member undertakes a partial responsibility and cooperates with other members to complete the project task.

6. Intermediate inspection: The rate of progress will be graded for each group.

7. Final check: The integrated electronic system object, experimental data and results developed by each group will be checked and graded.

8. Written report: Each group is supposed to hand in a written report. The report will be reviewed in terms of format and graded.

9. Final presentation: Students are supposed to give a final presentation.

\subsection{Performance evaluation}

The performance of each student is evaluated during the whole process. Final score is comprehensively evaluated by an instructor group through discussion according to the performance of student at each stage in each section, as well as the achievement quality and level. The ratios for all sections are shown in Tab 2.

Tab 2 Score ratios $(\%)$

\begin{tabular}{|c|l|c|c|c|c|}
\hline $\begin{array}{l}\text { Schematic } \\
\text { formulation }\end{array}$ & $\begin{array}{l}\text { Achievement } \\
\text { quality }\end{array}$ & Final report & Presentation & Cost control & teamwork \\
\hline 20 & 40 & 15 & 10 & 5 & 10 \\
\hline
\end{tabular}




\section{Conclusion}

We started IDOIS in 2009. Over the past eight years, we have continued to sum up our experience, update our design content, add new projects, and eliminate obsolete or unsuitable projects. The vast majority of students can seriously complete the subject requirements. The physical acceptance results show that each group can complete the basic functional requirements and technical requirements. Scores are given according to the comprehensive performance of each student. Some outstanding students have the ability to carry out independent scientific research. The student's harvest is great, mainly in the professional knowledge, theory and practical ability.

\section{Acknowledgment}

This work is also supported by Key Projects of Education and Teaching Reform in Beijing Higher Education [2015-zd10] and Key Teaching Reform of BISTU [2015zdjg04] and Key Curriculum Construction - Teaching Methodology Reform Project of BISTU [2014KG18]

\section{REFERENCE}

[1] Huang Shanglian. Optoelectronic information industry - 21st century high-tech leading industry [J]. College enrollmen,2000(06):1 4

[2] Lv Yong, Lv Naiguang, Deng Wenyi, et al. Exploration and practice on application oriented talents cultivation of optical information science and technology program [C] // $2006-2010$ Teaching and Research Subcommittee and Collaborative Committee of Optoelectronic Information Science and Engineering in Higher Education 2010 Annual Conference Proceedings.

[3] Zhong Qiquan, An Guiqing. Comprehensive Practical Activity Course: Substance, Potential and Problem [J]. Peking University Education Review, 2003, 1(3):66-69.

[4] Zhang Hua. Integrated practice curriculum: concept and framework [J]. Educational Development Research, 2001(1):44-47. 